\title{
Pemanfaatan Media Sosial Sebagai Sarana Komunikasi Publik Terkait dengan Penanggulangan COVID-19 (Studi Deskriptif Kualitatif pada Akun Instagram @ikpdinaskominfobabel)
}

\author{
Sofian Arissaputra ${ }^{1}$, Septia Winduwati ${ }^{2 *}$ \\ ${ }^{1}$ Fakultas Ilmu Komunikasi, Universitas Tarumanagara, Jakarta \\ Email: sofianlim14@gmail.com \\ ${ }^{2}$ Fakultas Ilmu Komunikasi, Universitas Tarumanagara, Jakarta* \\ Email: septiaw@fikom.untar.ac.id
}

Masuk tanggal : 15-12-2021, revisi tanggal :06-01-2022, diterima untuk diterbitkan tanggal : 16-01-2022

\begin{abstract}
This study aims to provide information and education related to the Covid-19 pandemic in the Bangka Belitung Islands, Pangkalpinang City through Instagram social media, especially on the @ikpdinaskominfobabel account. The information and education provided by the city government on the account is expected to protect Bangka Belitung so that it is free from the Covid-19 virus and there is no increase in cases of transmission. Where was the beginning of the typical Covid-19 began to appear, until it spread throughout the world and then entered Indonesia, especially Bangka Belitung. This research is a qualitative descriptive study. In collecting data, this research uses methods, such as interviews, documentation and literature study. The theory used is the theory of new media, Instagram as social media and public communication. The results of this study indicate that the information and education provided by the Bangka Belitung City Government regarding the prevention of Covid-19 distributed through Instagram with the @ikpdinaskominfobabel account is very useful for the people of Bangka Belitung. In addition, the results of this study provide an utilization of the Covid-19 countermeasures in Bangka Belitung by the government to the public through Instagram social media in overcoming Covid-19.
\end{abstract}

Keywords: covid-19, kepulauan bangka belitung province, covid-19 response

\begin{abstract}
Abstrak
Penelitian ini bertujuan untuk memberikan informasi dan edukasi terkait pandemi Covid-19 yang ada di Kepulauan Bangka Belitung, Kota Pangkalpinang melalui media sosial Instagram khususnya pada akun @ikpdinaskominfobabel. Adanya informasi dan edukasi yang diberikan pemerintah kota pada akun tersebut, diharapkan dapat melindungi Bangka Belitung agar terbebas dari virus Covid-19 dan tidak ada peningkatan dalam kasus penularannya. Penelitian ini merupakan penelitian deskriptif kualitatif. Dalam pengumpulan datanya, penelitian ini menggunakan metode, seperti wawancara, dokumentasi dan studi pustaka. Teori yang digunakan adalah teori new media, instagram sebagai media sosial dan komunikasi publik. Hasil dari penelitian ini menunjukkan bahwa informasi serta edukasi yang diberikan oleh Pemerintah Kota Bangka Belitung terkait penanggulangan Covid-19 yang disebarkan melalui Instagram dengan akun @ikpdinaskominfobabel sangat bermanfaat bagi masyarakat Bangka Belitung. Selain itu hasil dari penelitian ini memberikan sebuah pemanfaatan penanggulangan Covid-19 di Bangka Belitung oleh pemerintah kepada masyarakat melalui media sosial Instagram.
\end{abstract}

Kata Kunci: covid-19, provinsi kepulauan bangka belitung, penanggulangan covid-19 


\section{Pendahuluan}

COVID-19 pertama kali ditemukan dari Kota Wuhan, China, pada akhir Desember 2019. Pada 12 Maret 2020, virus ini mulai masuk ke Indonesia. Pada awalnya virus ini disamakan dengan pneumonia wuhan oleh pers karena memiliki gejala yang sama. Namun pada 12 Januari 2020 WHO menetapkan virus tersebut sebagai virus baru yang dinamai novel coronavirus (2019-nCoV) dan mengubah namanya menjadi COVID-19 pada 12 Februari 2020 (Nugroho, 2020). Dalam laporan Ilmu Organisasi Kesehatan Dunia (WHO), mengungkapkan bahwa virus Corona ditularkan oleh kelelawar melalui hewan perantara yang tidak dikenal sebelum menular ke manusia. Tim WHO menyebutkan bahwa virus corona SARS-CoV-2, muncul secara alami pada hewan kelelawar, sebelum diteruskan ke manusia melalui inang hewan perantara yang belum dikonfirmasi (Sumartiningtyas, 2021).

Adanya virus COVID-19 ini, menyebabkan seluruh negara dunia menghadapi krisis kesehatan dan sosial ekonomi yang belum pernah terjadi sebelumnya. Sehingga setiap kota dan negara melakukan penutupan atau lockdown, pembatalan penerbangan, hingga memberhentikan festival dan berbagai kegiatan lainnya. Meski begitu, setiap negara memiliki cara yang berbeda dalam penanganan COVID-19, contohnya adalah Prancis, sejak dinyatakan memiliki kasus pertama pada tanggal 25 Januari 2020. Pemerintah Prancis langsung menerapkan lockdown. Masyarakat kota Prancis hanya diperbolehkan keluar rumah untuk pergi ke mini market, ke apotek dan rumah sakit untuk konsultasi dengan dokter. Pemerintah Prancis juga menerapkan beberapa sanksi tegas seperti, denda sebesar 135 Euro bagi yang melanggar atau bepergian lebih dari 1 jam dalam jaraknya lebih dari 1 kilometer. Pemerintah Perancis juga menerapkan beberapa langkah utama dalam menangani Covid-19 seperti membentuk badan dewan ilmiah yang ahli di bidangnya.

Selain Prancis, Indonesia juga melakukan penanganan Covid-19. Pemerintah Indonesia mengambil langkah dan membuat kebijakan untuk menangani wabah virus corona. Tindakan yang diambil adalah dengan memerintahkan kedutaan Indonesia di China untuk memberi perhatian khusus terhadap Warga Negara Indonesia (WNI) yang terisolasi di Wuhan, China. Pemerintah Indonesia juga membangun 100 rumah sakit, memasangkan alat pendeteksi suhu tubuh di 135 bandar udara dan pelabuhan Internasional, selain itu juga melakukan pengawasan yang ketat pada setiap jalur masuk ke Indonesia (Gitiyarko, 2020).

Penyebaran kasus COVID-19 hampir merata di seluruh wilayah di Indonesia.Salah satunya Kota Pangkalpinang. Di kota ini terdapat pasien yang berumur 72 tahun meninggal karena terinfeksi virus korona (Dahnur, 2020). Peran pemerintah diwujudkan dalam kebijakan yang ditetapkan oleh pemprov Kepulauan Bangka Belitung untuk menghentikan penyebaran COVID-19, diantaranya adalah dengan melakukan GERMAS atau gerakan masyarakat hidup sehat. Selain itu persiapan rumah sakit rujukan COVID-19 juga disediakan oleh pemprov Babel, di RSUD Depati Hamzah Kota Pangkalpinang (Adit, 2020).

Seiring berjalannya waktu kasus COVID-19 di Kota Pangkalpinang terus meningkat. Disinilah peran Pemerintah Kota Pangkalpinang mulai terlihat dalam memberikan pemanfaatan media sosial sebagai sarana komunikasi terkait dengan penanggulangan Covid-19 melalui akun instagram @ikpdiskominfobabel. Akun @ikpdiskominfobabel ini memiliki 2 akun resmi, yang pertama pada akun @Diskominfobabel. Akun ini lebih menceritakan tentang seputaran harian pada kondisi atau informasi yang ada di Bangka Belitung. Lalu pada akun kedua 
Sofian Arissaputra, Septia Winduwati: Pemanfaatan Media Sosial Sebagai Sarana Komunikasi Publik Terkait dengan Penanggulangan COVID-19 (Studi Deskriptif Kualitatif pada Akun Instagram @ikpdinaskominfobabel)

@ikpdinaskominfobabel akun ini berisi informasi data-data Covid-19, seperti data jumlah virus corona, informasi tentang Covid-19 hingga kesehatan. Media sosial Instagram digunakan oleh Pemerintah Provinsi Bangka Belitung guna mensosialisasikan program kesehatan pada masyarakat. Instagram merupakan media sosial yang banyak diakses oleh masyarakat dan digunakan mulai dari anak muda hingga lansia yang cenderung menggunakan Instagram untuk mendapatkan informasi lebih lanjut mengenai perkembangan kasus COVID-19.

Terdapat beberapa penelitian terdahulu yang fokus untuk meneliti peranan media sosial seperti Facebook dan Instagram selama pandemi COVID-19. Penelitian pertama oleh Akasse, Akbar dan Arianto (2021) yang bertujuan untuk meneliti Penggunaan Facebook dalam penyampaian informasi yang digunakan oleh pemerintah provinsi Gorontalo. Hasil dari penelitian ini menunjukan bahwa Facebook digunakan oleh pemerintah Gorontalo melalui Humas untuk memberikan informasi yang kredibel seputar COVID-19 kepada masyarakat. Selanjutnya penelitian dari Attaymini (2020) yang meneliti penggunaan Facebook selama masa pandemi COVID-19 di Masjid Nurul Huda, Ngoto, Sewon, Bantul, Yogyakarta. Penelitian ini menemukan bahwa komunikasi digital melalui media sosial Facebook yang digunakan oleh Masjid Nurul Huda Ngoto bertujuan untuk mengedukasi dan berdakwah. Sehingga masyarakat memiliki sumber informasi kegiatan keagamaan di masjid dan masyarakat diharapkan dapat lebih semangat dalam beribadah di rumah masing-masing pada selama pandemi COVID-19 masih berlangsung.

Kemudian penelitian dari Iqbal (2021) yang melakukan studi untuk melihat peranan media sosial Instagram dalam pencegahan COVID-19 pada Mahasiswa Ilmu Komunikasi Universitas Muhammadiyah Jember. Hasil penelitian ini menunjukkan bahwa mahasiswa ilmu komunikasi mengetahui ragam hastag platform di Instagram dan mampu bertindak secara efektif, apa yang mereka pelajari dari berbagai informasi terkait penanganan penyebaran virus COVID-19, layanan atau fitur dari platform instagram juga menyediakan pengetahuan dan mengajarkan masyarakat cara hidup sehat serta mengungkapkan sudut pandang berbeda dalam menghadapi pandemi ini. Berdasarkan penjelasan diatas dapat disimpulkan bawa terdapat banyak penelitian terdahulu yang berfokus pada peranan dan penggunaan media sosial sebagai sarana memberikan informasi selama pandemi COVID-19 namun hanya sedikit yang berfokus untuk menganalisis pemanfaatan media sosial sebagai sarana komunikasi publik terkait penanggulangan COVID-19 yang digunakan oleh pemerintah.

Tidak seperti penelitian terdahulu yang hanya berfokus untuk menganalisis penggunaan media sosial sebagai sarana memberikan informasi selama pandemi COVID-19, penelitian deskriptif kualitatif ini tidak hanya bertujuan untuk melihat kegunaan media sosial sebagai sebuah sarana membagikan informasi namun juga sarana komunikasi publik terkait dengan penanggulangan COVID-19 terutama di Bangka Belitung.

\section{Metode Penelitian}

Penelitian ini menggunakan metode studi kasus. Dalam penelitian studi kasus, analisis haruslah maksimal dalam berbagai aspek yang terkait, sehingga dapat diperoleh kesimpulan yang rinci (Sutedi, 2009). Selain itu dalam studi kasus, penelitian hanya dipusatkan pada satu objek tertentu untuk memperoleh gambaran yang fokus tentang kasus tersebut. Penelitian ini bertujuan untuk mengetahui suatu kegiatan, proses dan peristiwa yang dilakukan dalam media sosial, khususnya 
Instagram, pada akun Pemerintah Provinsi Kepulauan Bangka Belitung, khususnya di Kota Pangkalpinang dalam meningatkan informasi yang dibagikan kepada publik. Subjek dalam penelitian adalah pengelola atau humas Provinsi Kepulauan Bangka Belitung. Sedangkan objek dalam penelitian ini adalah pemanfaatan media sosial Instagram Pemerintah Provinsi Kepulauan Bangka Belitung sebagai sarana komunikasi, dalam hal ini terkait dengan penanggulangan Covid-19.

Untuk mengumpulkan data, peneliti menggunakan teknik wawancara, studi dokumentasi dan studi kepustakaan. Wawancara dilakukan secara langsung dengan admin Instagram Pemerintah Provinsi Kepulauan Bangka Belitung. Kemudian studi dokumentasi dilakukan dengan cara mengumpulkan data kualitatif dengan menganalisis, ataupun melihat video, autobiografi dan berita terkait Pemerintah Provinsi Kepulauan Bangka Belitung dengan upaya penanggulangan Covid-19 nya. Terakhir, studi kepustakaan dilakukan untuk menghimpun data primer atau sekunder tentang media sosial Instagram pada akun @ Ikpkominfobabel dalam penanggulangan covid-19. Kemudian data yang dikumpulkan dikategorikan, disatukan sebelum pada akhirnya ditafsirkan atau dianalisis dengan menggunakan teori yang menjadi acuan dalam proses analisis yang bertujuan agar memudahkan pembaca untuk memahami.

\section{Hasil Penemuan dan Diskusi}

Dalam penelitian ini hasil temuan didapatkan dari wawancara dengan responden. Berikut ini adalah detail temuan dalam penelitian:

\section{Penyampaian Informasi kepada Masyarakat Publik dalam Penanganan Covid-} 19

Pemerintah Provinsi Kepualauan Banga Belitung menggunakan media sosial seperti Facebook dan Instagram untuk menyampaikan informasi kepada masyarakat. Sebelum menggunakan media sosial tersebut, Pemerintah sebelumnya melakukan riset terkait penggunaan media sosial di Bangka Belitung.

"Pertama yang Pemerintah lakukan adalah mereset penggunaan sosial media di Bangka Belitung pada media sosial Facebook, Instagram, ataupun WhatsApp. Dan hasilnya riset Pemerintah, lebih menggunakan media sosial Facebook dan Instagram karena pengguna sosial media tersebut lebih banyak penggunanya di bangka Belitung." - Leo Randika sebagai KASI Pengelolaan dan Penyediaan Informasi.

Berdasarkan hasil riset yang dilakukan oleh Pemerintah Provinsi Kepulauan Bangka Belitung, Pemerintah lebih memilih untuk menggunakan Facebook dan Instagram untuk memberikan informasi kepada masyarakat.

\section{Peran Pemerintah pada Akun Instagram @ikpdinaskominfobabel}

Akun@ikpdinaskominfobabel digunakan oleh Pemerintah untuk memberikan informasi kepada masyarakat, khususnya kepada masyarakat Bangka Belitung. Informasi yang sebelumnya didapat dari pemerintah pusat diteruskan dan disebarkan oleh Pemerintah Bangka Belitung melalui media sosial Instagram.

"Tujuan Pemerintah pada akun sosial media Instagram @ikpdinaskominfobabel untuk memberikan informasi kepada masyarakat 
Sofian Arissaputra, Septia Winduwati: Pemanfaatan Media Sosial Sebagai Sarana Komunikasi Publik Terkait dengan Penanggulangan COVID-19 (Studi Deskriptif Kualitatif pada Akun Instagram @ikpdinaskominfobabel)

dengan cepat khususnya pada Provinsi Kepulauan Bangka Belitung. Informasi yang kami dapatkan dari Pemerintahan pusat akan kami sebarkan dengan secepatnya dengan sosial media Instagram. - Leo Randika sebagai KASI Pengelolaan dan Penyediaan Informasi.

Masyarakat memang seharusnya mendapatkan informasi yang kredibel dari pemerintah. Pemerintah dapat meneruskan informasi yang disampaikan oleh pemerintah pusat kepada masyarakat luas, terkait dengan pendataan atau informasi lain yang diberikan oleh pemerintah pusat.

\section{Penyampaian Pemerintah kepada Masyarakat}

Dalam menyampaikan informasi kepada masyarakat, Pemerintah daerah Bangka Belitung membuat konten-konten instagram yang berhubungan dengan COVID-19. Konten tersebut dapat memuat informasi seperti data COVID-19, seperti jumlah masyarakat yang meninggal, yang terinfeksi dan yang sembuh. Selain itu ajakan dan sosialisasi penerapan protokol kesehatan $3 \mathrm{M}$ juga menjadi salah satu kontennya.

"Melalui media sosial Facebook hingga Instagram diskominfo memberikan informasi kepada masyarakat seperti data Covid-19, data yang terinfeksi, jumlah data yang meninggal hingga memberikan konten-konten seperti ajakan dalam bentuk penerapan protokol kesehatan 3M." - Leo Randika sebagai KASI Pengelolaan dan Penyediaan Informasi.

Dengan menggunakan Facebook dan Instagram, pemerintah lebih mudah dan cepat dalam memberikan informasi kepada masyarakat melalui konten-konten terkait COVID-19. Dikarenakan media sosial banyak digunakan dan efektif dalam memberikan informasi kepada masyarakat dalam kurun waktu yang singkat.

\section{Kebijakan Pemerintah Provinsi Babel Penanggulangan Covid-19}

Kebijakan pemerintah pusat terkait penanganan dan penanggulangan COVID19 terus berubah, seiring dengan perkembangan pengetahuan dan penelitian. Dikarenakan cepatnya perubahan kebijakan tersebut. Media sosial seperti Facebook dan Instagram sangat dibutuhkan untuk menyebarkan informasi terbaru kepada masyarakat dengan cepat dan tepat.

"Kebijakan Pemerintah pada Covid-19, kebijakan tersebut akan dapat berganti terus-menerus. Kebijakan Pemerintah dapat berubah perhari, pertiga hari atau bisa mingguan. Kebijakan tersebut tidak konsisten, yang diberikan oleh Pemerintah. Contohnya: dulu pada saat awal corona melanda kita dianjurkan menggunakan masker 1 lapis, tahun depannya Pemerintah menerapkan masyarakatnya menggunakan 2 masker. maka dari itulah informasi dalam kebijakan Pemerintah harus disebarkan dengan cepat dengan menggunakan sosial media Instagram dan Facebook." - Leo Randika sebagai KASI Pengelolaan dan Penyediaan Informasi.

Kebijakan pemerintah pusat dapat berubah dan mengalami perkembangan setiap saat. Oleh karena itu pemerintah daerah haruslah cepat dalam menyebarkan informasi terkait kebijakan tersebut. Media sosial merupakan sarana yang sangat efektif dan efisien yang dapat digunakan saat ini. 


\section{Koordinasi dengan Pemerintah Pusat}

Tidak ada koordinasi yang dilakukan oleh pemerintah daerah provinsi Kepulauan Bangka belitung dan pemerintah pusat. Menurut responden Leo Randika sebagai KASI pengelolaan dan penyediaan informasi kebijakan, pemerintah daerah hanya meneruskan informasi dari pemerintah pusat kepada masyarakat terkait COVID-19.

"Kebijakan dalam Pemerintahan pusat itu tidak ada, namun biasanya kebijakan dari pusatlah yang akan kami bagikan kepada masyarakat.” - Leo Randika sebagai KASI Pengelolaan dan Penyediaan Informasi.

Kebijakan pemerintah pusat belum tentu dapat diimplementasikan sepenuhnya di daerah.

"Dalam kebijakan Pemerintah pusat sudah turun belum tentu kebijakan dari pusat bisa digunakan sepenuhnya oleh daerah." - Leo Randika sebagai KASI Pengelolaan dan Penyediaan Informasi

Berikut adalah konten dari media sosial Instagram @ikpdinaskominfobabel yang digunakan oleh Pemerintah Provinsi Kepulauan Bangka Belitung untuk menyampaikan informasi terkait dengan Covid-19. Konten-konten tersebut merupakan fakta yang diberikan dalam 3 bulan belakangan ini.

Gambar 1. Instagram @ikpdinaskominfobabel 26 Oktober 2021

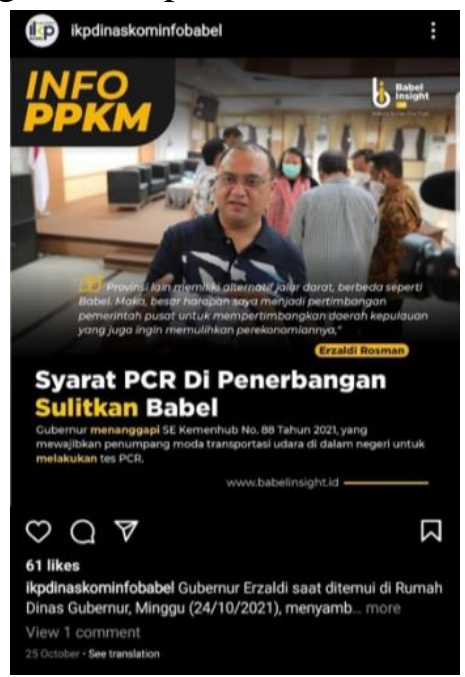

Sumber: Instagram

Hasil screenshot didapatkan pada tanggal, 24 November 2021 dari akun @ikpdinaskominfobabel. Konten tersebut di posting pada tanggal 26 Oktober 2021. Postingan tersebut menjelaskan SE atau surat edaran Kementerian Perhubungan Nomor 88 Tahun 2021. Postingan ini diungkapkan oleh Gubernur Provinsi Kepulauan Bangka Belitung, yang menyampaikan kebijakan pemerintah pusat yang mewajibkan penumpang moda transportasi udara melakukan tes Polymerase Chain Reaction (PCR). Hal ini bertujuan agar maskapai dapat mengisi kursi penumpang sebanyak $100 \%$. Selain itu gubernur juga meminta pemerintah pusat untuk meninjau kembali kebijakan tersebut. Di postingan tersebut gubernur juga menyatakan bahwa Provinsi 
Sofian Arissaputra, Septia Winduwati: Pemanfaatan Media Sosial Sebagai Sarana Komunikasi Publik Terkait dengan Penanggulangan COVID-19 (Studi Deskriptif Kualitatif pada Akun Instagram @ikpdinaskominfobabel)

Kepulauan Bangka belitung memiliki alternatif jalur darat seperti tol trans Jawa, Trans Kalimantan, Trans sulawesi yang menjadi alasan utama nya.

Gambar 2. Instagram @ikpdinaskominfobabel 22 Oktober 2021

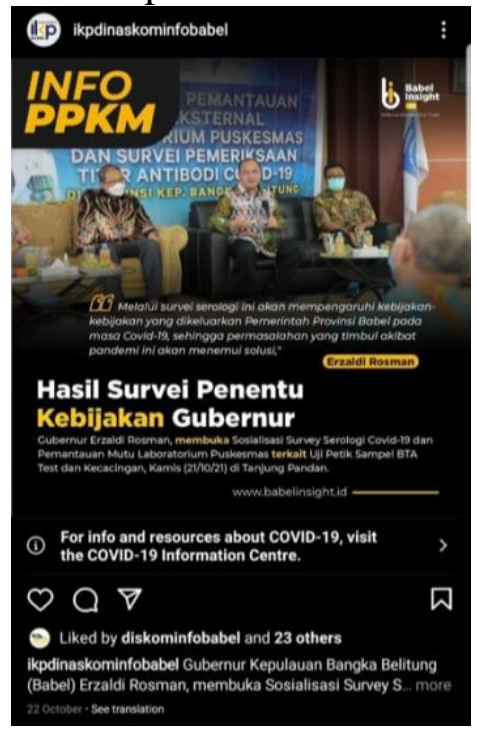

Sumber: Instagram

Hasil screenshot diatas didapatkan pada tanggal 24 November 2021 dari akun Instagram @ikpdinaskominfobabel. Postingan tersebut diunggah pada tanggal 22 Oktober 2021, dimana Gubernur Provinsi Kepulauan Bangka Belitung melakukan sosialisasi dan survey COVID-19 dan pemantauan Laboratorium Puskesmas terkait Uji Pratik Sampel BTA Test. Tujuan pemantauan tersebut untuk melihat kemampuan para analis dan kesiapan Laboratorium pada masing-masing puskesmas. Terdapat kutipan yang diungkapkan oleh Gubernur Provinsi Kepulauan Bangka Belitung Erzaldi Rosman pada postingan diatas.

"Melalui survei serologi ini akan mempengaruhi kebijakan-kebijakan yang dikeluarkan Pemerintah Provinsi Babel pada masa Covid-19, sehingga permasalahan yang timbul akibat pandemi ini akan menemui solusi." [Gubernur Provinsi Kepulauan Bangka Belitung Erzaldi Rosman].

Gambar 3. Instagram @ikpdinaskominfobabel 26 October 2021

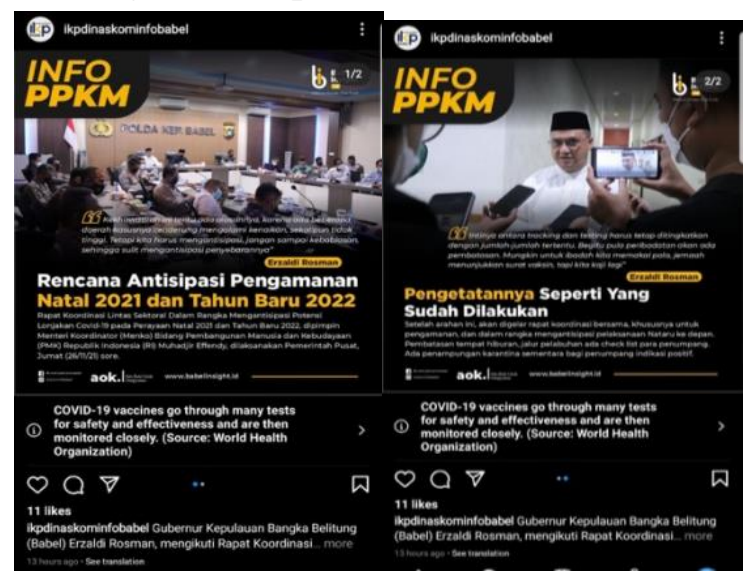

Sumber: Instagram 
Gambar di atas merupakan hasil screenshot tanggal 27 November 2021. Konten tersebut diunggah pada tanggal 27 November 2021. 2 postingan di atas merupakan hasil Rencana Antisipasi Pengamanan Natal 2021 dan Tahun baru 2022. Rapat tersebut bertujuan untuk mengantisipasi lonjakan kasus Covid-19 pada Perayaan Natal 2021 dan tahun baru 2022. Rapat yang dilaksanakan oleh pemerintah pusat tersebut, dipimpin oleh Menteri Koordinator (Menko) Bidang Pembangunan Manusia dan Kebudayaan (PMK) Republik Indonesia (RI), Muhadjir Effendy.

Pada postingan pertama terdapat kutipan dari Erzaldi Rosman, selaku Gubernur Provinsi Kepulauan Bangka Belitung.

"Kekhawatiran ini tentu ada alasannya, karena ada beberapa daerah kasusnya cenderung mengalami kenaikan, sekalipun tidak tinggi. Tetapi kita harus mengantisipasi, jangan sampai kebablasan, sehingga sulit mengantisipasi penyebarannya." [Gubernur Provinsi Kepulauan Bangka Belitung Erzaldi Rosman].

Pada postingan kedua juga terdapat kutipan dari gubernur Provinsi Kepulauan Bangka Belitung.

"Intinya antara tracking dan testing harus tetap ditingkatkan dengan jumlahjumlah tertentu. Begitu pula peribadatan akan ada pembatasan. Mungkin untuk ibadah kita memakai pola, jemaah menunjukkan surat vaksin, tapi kita kaji lagi.” [Gubernur Provinsi Kepulauan Bangka Belitung Erzaldi Rosman].

Dapat disimpulkan bahwa, Pemerintah Provinsi Kepulauan Bangka Belitung memanfaatkan media sosial Instagram sebagai upaya penanggulangan Covid-19. Hal tersebut bertujuan agar masyarakat lebih cepat mendapatkan informasi dalam penanganan Covid-19. Hal tersebut terkait dengan teori komunikasi publik, dimana Pemerintah memberikan dan menyampaikan informasi kepada masyarakat melalui media sosial. Media sosial itu sendiri, merupakan media yang sangat efektif untuk memberikan dan menyampaikan informasi kepada masyarakat.

Media sosial yang efektif adalah media sosial yang dapat memberikan informasi kepada masyarakat. Seperti yang dilakukan oleh Pemerintah Provinsi Kepulauan Bangka Belitung melalui media sosial Instagram dengan akun @ikpdinaskominfobabel yang juga bertujuan untuk memberikan informasi kepada masyarakat, salah satunya informasi tentang perkembangan kasus Covid-19 Provinsi Kepulauan Bangka Belitung, sebagai upaya penanggulangan. Dengan menggunakan media sosial Instagram, informasi yang dibagikan akan lebih cepat tersebar luas dalam kurun waktu singkat yang berbeda dengan koran yang akan dipublikasikan pada hari berikutnya(Nasrullah, 2017).

Media sosial dapat digunakan sebagai sarana hiburan, selain itu juga dapat menjadi media untuk menyampaikan informasi antar sesama penggunanya. Seperti akun media sosial Instagram milik Pemerintah Provinsi Kepuluan Bangka Belitung @ikpdinaskominfobabel yang digunakan untuk memberikan informasi kepada masyarakat terkait dengan Covid-19 sebagai salah satu upaya penanggulangan. Contohnya dalam akun media sosial @ikpdinaskominfobabel tersebut, pemerintah memberikan informasi penerapan PPKM, selain itu juga bertujuan untuk menjalin interaksi guna mempererathubungan antar pemerintah dengan masyarakat seperti melakukan quiz. Junaedi (2019) menambahkan bahwa media sosial sangatlah penting 
Sofian Arissaputra, Septia Winduwati: Pemanfaatan Media Sosial Sebagai Sarana Komunikasi Publik Terkait dengan Penanggulangan COVID-19 (Studi Deskriptif Kualitatif pada Akun Instagram @ikpdinaskominfobabel)

untuk masyarakat di era ini. Semua orang bergantung dan tidak dapat lepas dari media sosial.

Teori komunikasi publik menitikberatkan pada penyampaian informasi dan interaksi antara pemerintah dan masyarakat. Pemerintah Provinsi Kepulauan Bangka Belitung memanfaatkan media sosial instagram untuk memberikan informasi seputar perkembangan Covid-19. Selain itu juga menyampaikan informasi perkembangan di bidang sosial, ekonomi dan lainnya. Kontennya pun beragam, mulai dari foto, video dan interaksi berupa kuis. Dengan begitu, komunikasi publik Pemerintah Provinsi Kepulauan Bangka Belitung dapat berjalan lebih efektif. Dalam hal ini pemerintah Provinsi Kepulauan Bangka Belitung terus berusaha melakukan berbagai inovasi dalam memberikan konten-konten informatif kepada masyarakat khususnya pada akun Instagram@ikpdinaskominfobabel.

\section{Simpulan}

Media sosial seperti Instagram banyak dimanfaatkan, terutama di masa pandemi Covid-19 yang dialami saat ini. Pemerintah dapat berinteraksi dengan masyarakat menggunakan media sosial. Selain itu, media sosial sebagai sarana komunikasi publik juga digunakan untuk menginformasikan tentang Covid-19 kepada masyarakat. Pemerintah menggunakan media sosial sebagai sarana komunikasi publik untuk dapat menanggulangi Covid-19, agar masyarakat Provinsi Kepulauan Bangka Belitung terbebas dari virus Covid-19 dan dapat melakukan aktivitas sebagaimana biasanya. Pemerintah memanfaatkan media sosial khususnya Instagram sebagai sarana komunikasi publik dimaksudkan supaya masyarakat dapat lebih cepat mendapatkan informasi yang disebarkan oleh pemerintah. Dengan menggunakan teori komunikasi publik, pemerintah memberikan informasi seputar Covid-19 kepada masyarakat.

\section{Ucapan Terima Kasih}

Peneliti ingin mengucapkan terima kasih kepada Fakultas Ilmu Komunikasi Universitas Tarumanagara, narasumber, serta semua pihak yang turut membantu peneliti sehingga penelitian ini dapat diselesaikan.

\section{Daftar Pustaka}

Adit. (2020, 24 Maret). Bersama Lenyapkan Covid-19 Babel Harus Kuat!! Diperoleh 03 Agustus 2021 dari https://babelprov.go.id/content/bersama-lenyapkancovid-19-babel-harus-kuat

Akasse, C. S., Akbar, M., \& Arianto, A. (2012). Analisis Facebook dalam Penyampaian Informasi Covid-19 oleh Pemerintah Provinsi Gorontalo. Syntax Literate; Jurnal Ilmiah Indonesia, 6(7), 3185-3198. DOI: http://dx.doi .org/10.36418/syntaxliterate.v6i7.3456

Attaymini, Rahmah. (2020). Pemanfaatan Facebook selama Masa Pandemi Covid-19 Di Masjid Nurul Huda, Ngoto, Sewon, Bantul, Yogyakarta. Jurnal PIKMA: Publikasi Ilmu Komunikasi Media Dan Cinema,3(1), 34-46. DOI: https://doi.org/10.24076/PIKMA.2020v3i1.354

Dahnur, Heru. ( 2020, 09 April). Pasien Positif Corona di Bangka Belitung Bertambah Jadi 3 Orang. Diperoleh 01 Agustus 2021 dari https://regional.ko 
mpas.com/read/2020/04/09/07444461/pasien-positif-corona-di-bangkabelitung-bertambah-jadi-3-orang

Gitiyarko, Vincentius. (2020, 26 April ). Gugus tugas percepatan Penanganan Covid19. Diperoleh 3 Agustus 2021 dari https://kompaspedia.kompas.id/baca/profil/lembaga/gugustugas percepatan-penanganan-covid-19-2

Iqbal, Budiman. (2021). Peran Media Sosial Instagram dalam Pencegahan Covid19 pada Mahasiswa Ilmu Komunikasi Universitas Muhammadiyah Jember. Undergraduate Thesis. Universitas Muhammadiyah Jember. http://repository.unmuhjember.ac.id/10868/

Junaedi, Fajar. (2019).Etika Komunikasi di Era Siber. Yogyakarta: Rajawali

Nasrullah, Rulli. (2017). Media Sosial : Perspektif Komunikasi, Budaya dan Sosioteknologi. Bandung:Remaja Rosdakarya.

Nugroho, R.S. (2020, Desember 2). Ini Alasan WHO Memberi Nama Resmi Covid 19 untuk Virus Corona. Retrieved from https://www.kompas.com/tren $/ \mathrm{read} / 2020 / 02 / 12 / 063200865 /$ ini-alasan-who-memberi-nama-resmi-covid-19untuk-virus-corona?page $=$ all

Sumartiningtyas, H.K.N. (2021, 30 Maret). WHO Sebut Sangat Mungkin Virus Corona. https://www.kompas.com/sains/read/2020/03/12/083129823/whoresmi-sebut-virus-corona-covid-19-sebagai-pandemi-global?page=all

Sutedi, Adrian. (2009). Metode Penelitian Hukum. Jakarta: Sinar Grafika. 